\title{
Rattlesnake Fibroma
}

National Cancer Institute

\section{Source}

National Cancer Institute. Rattlesnake Fibroma. NCI Thesaurus. Code C134999.

A fibroma that occurs in a rattlesnake. 